\title{
PAHLAWAN: SIAPA MEREKA? PENDEKATAN PSIKOLOGI INDIGENOUS
}

\author{
Bony Yulvia Azri* \& Ivan Muhammad Agung ${ }^{\dagger}$ \\ Fakultas Psikologi UIN Sultan Syarif Kasim, Riau \\ *Email: Bony.blu3@gmail.com \\ †Email: ivan.agung@uin-suska.ac.id
}

\begin{abstract}
Abstrak
Pahlawan merupakan istilah yang banyak digunakan di budaya Indonesia. Pahlawan merujuk pada diri seseorang karena keberanian, kekuatan, pengorbanan dan kemampuan untuk mengatasi permasalahan. Beberapa penelitian tentang pahlawan dalam perpektif psikologi telah banyak dilakukan di Barat. Namun penelitian konsepsi pahlawan dalam perspektif psikologi di Indonesia masih jarang atau belum dilakukan. Penelitian ini bertujuan untuk mengeskplorasi siapa dan apa karakteristik pahlawan pada mahasiswa. Penelitian menggunakan pendekatan psikologi indigenous dengan pertanyaan terbuka. Respon jawaban dikode, dikategori, dan dianalisis menggunakan analisis kualitatif dan kuantitatif. Partisipan adalah mahaisswa UIN sultan Syarif Kasim Riau berjumlah 300 mahasiswa (rerata umur 21 tahun). Hasil penelitian menunjukkan bahwa sebagian besar menjadikan orangtua sebagai pahlawan (64,3\%), tokoh nasional/komunitas $(17,3 \%)$ dan pendidik (16,7\%) dan terdapat delapan karakteristik pahlawan, yaitu, dominan (24.67\%), peduli (19\%), karismatik (13\%), inspiratif (11,67\%), tangguh (9,66\%), tanpa pamrih (9\%), mendidik (8,67\%) dan terpercaya (4,33\%). Implikasi hasil penelitian dibahas dalam konteks budaya Indonesia.
\end{abstract}

Kata kunci: pahlawan, karakter, indigenous psychology

\begin{abstract}
Hero is a term that often used in Indonesia. Heroes refer to a person because of courage, strength, sacrifice and ability to overcome problems. Some research on heroes in the perspective of psychology has been widely practiced in the West. However, hero in the perspective of psychology in Indonesia is still rarely investigated. This study aims to explore who and what characteristics of heroes by students. Research was using indigenous psychology approach by providing an open-ended question. The responses were coded, categorizationed, and analyzed which were using qualitative and quantitative analysis. Participants in the study were 300 students of UIN Sultan Syarif Kasim Riau, Indonesia. The result shows that participants considered the hero who are parent (64.3\%), national leaders/community (17.3\%) and teachers (16.7\%). The analysis shows there are eight categories of heroes's characteristics, which are dominant (24.67\%), caring (19\%), charismatic (13\%), inspiring (11.67\%), resilient (9.66\%), selfless (9\%), teaching (8.67\%) and reliable (4.33\%). The implications of this research will be discussed in the context of Indonesian culture.
\end{abstract}

Keywords: characteristics, heroes, indigenous psychology 


\section{Pendahuluan}

Siapakah pahlawan? Apakah perbedaan antara pahlawan dengan pemimpin atau panutan? Pada wacana populer, interpretasi modern tentang pahlawan dan selebriti kadang-kadang tidak berbeda. Selebriti dan bintang olahraga sering dianggap sebagai pahlawan media. Setelah bencana, orang-orang yang menyelamatkan dan membangun kembali masyarakat dianggap sebagai pahlawan. Secara pribadi, orang menganggap keluarga sebagai pahlawan. Batas konseptual antara pemimpin, panutan, dan pahlawan menjadi tidak jelas (Kinsella, dkk., 2015a).

Konsep kepahlawanan telah berubah dari generasi ke generasi. Akibatnya, pertanyaan tentang bagaimana mendefinisikan pahlawan menimbulkan banyak perdebatan (Allison \& Goethals, 2011). Pada wacana populer, interpretasi modern tentang pahlawan dan selebriti kadang-kadang tidak berbeda. Selebriti dan bintang olahraga sering dianggap sebagai pahlawan media. Setelah bencana, orang-orang yang menyelamatkan dan membangun kembali masyarakat dianggap sebagai pahlawan. Definisi dan konsepsi pahlawan sangat tergantung pada konteks, yang meliputi situasi dan budaya (Franco, dkk. 2011)

Kepahlawan memiliki kedudukan penting dalam ruang lingkup personal maupun kelompok atau organisasi (Negara). Data survei dari penelitian di USA mengungkapkan bahwa $66 \%$ dari orang dewasa yang menjadi sampel penelitian di 25 negara setidaknya memiliki satu pahlawan pribadi (Kinsella, Ritchie, \& Igou, 2010). Penelitian sebelumnya menemukan kategori fungsi pahlawan yakni untuk menyimpan, menanamkan harapan, meningkatkan semangat dan persahabatan, membuat dunia menjadi tempat yang lebih baik, dan mengingatkan orang-orang tentang kebaikan dunia (Kinsella, Ritchie, \& Igou, 2015a).

Aspek yang paling penting dari kepahlawanan adalah dampak dari sikap pahlawan terhadap pengikutnya dan dalam bermasyarakat (Franco, Blau, \& Zimbardo, 2011). Pahlawan dapat mempengaruhi cara orang merasa, berpikir, dan bertindak. Ciri khas pahlawan adalah memiliki kharisma dan daya tarik, dapat menggerakkan individu, dan menginspirasi. Pahlawan juga mempengaruhi pemikiran individu ke tingkat yang lebih signifikan dan menunjukkan kepada individu bagaimana berperilaku baik (Goethals \& Allison, 2012). Pahlawan dijelaskan dalam literatur dapat mengangkat dan meningkatkan kehidupan orang lain (Kinsella, Ritchie, \& Igou, 2015b). Pahlawan dapat membangkitkan emosi positif seperti, rasa syukur atau kekaguman (Algoe \& Haidt, 2009). Orang mungkin mengalami hal positif akibat dikaitkan dengan prestasi yang luar biasa oleh pahlawan mereka (Allison \& Goethals, 2011).

Kata pahlawan berasal dari kata Yunani untuk pahlawan atau pejuang (Goethals \& Allison, 2012). Etimologi kata pahlawan (dari pahlawan Yunani) menunjukkan bahwa pahlawan melindungi orang lain (Harper, 2010). Menurut Kamus Besar Bahasa Indonesia (KBBI) pahlawan berarti orang yang menonjol karena keberanian dan pengorbanannya dalam membela kebenaran, pejuang yang gagah berani. Pahlawan digambarkan sebagai pemodelan dan nilai moral (Kinsella, dkk., 2015b). Pahlawan dapat memotivasi individu menjadi orang yang lebih baik dengan meningkatkan kesadaran atau diri ideal (Klapp, 1969).

$$
\text { Goethals dan Allison (2012) }
$$

menemukan delapan ciri utama kepahlawanan, yaitu (1) peduli: penuh kasih, empati, baik (2) karismatik: berdedikasi, fasih, bergairah (3) inspiratif: mengagumkan, menakjubkan, besar, inspirasional (4) terpercaya: setia, benar (5) tangguh: pencapaian, bertekad, tekun (6) tanpa pamrih: altruistik, jujur, rendah hati, bermoral (7) pintar: cerdas, bijaksana (8) kuat: berani, mendominasi, gagah, pemimpin.

Pahlawan juga dapat membantu orang untuk memahami norma-norma dan nilai-nilai dalam masyarakat (Cohen, 
1993). Nilai Kepahlawan membantu individu merperbaiki makna diri dan memotvasi diri (Coughlan, et.al .2017). Demikian pula, individu sering berusaha untuk menciptakan kehidupan yang bermakna berdasarkan pada nilai-nilai masyarakat, sering dimodelkan oleh pahlawan. Melalui cara-cara seperti itu, orang menciptakan dampak yang langgeng dan mencapai keabadian simbolis (Goethals \& Allison, 2012).

Pada penelitian Porpora (1996) juga dijelaskan alasan pentingnya meneliti pahlawan. Seorang individu dibentuk bukan hanya dari lingkungan sosial saja, tetapi juga dalam ruang moral. Pahlawan merupakan salah satu model bagi individu dalam mengidentifikasi nilai, norma, dan aspirasi (Bricheno \& Thornton, 2007). Nilai, norma, dan aspirasi pahlawan tersebut kemudian diaplikasikan pada diri individu dan mencerminkan siapa individu dalam budaya individual atau kolektif. Indvidu yang memiliki nilai pahlawan tinggi cenderung penolong (Staats, dkk. 2009) Jadi pahlawan adalah orang yang memperjuangkan kebenaran, mengabdikan diri mereka untuk membantu orang lain tanpa mengharap imbalan.

Kepahlawanan menjadi topik yang cukup diabaikan dalam psikologi (Sullivan \& Venter, 2005), terlepas dari apakah kepahlawanan memberi dampak yang positif atau negatif, topik mengenai pahlawan mendapat perhatian yang relatif sedikit dari psikolog (Jayawickreme \& Stefano, 2012). Hanya baru-baru ini upaya empiris untuk memahami kepahlawanan menjadi daya tarik untuk diteliti (Franco, dkk., 2011), serta peningkatan kepentingan ilmiah dan praktis dalam psikologi kepahlawanan (Kinsella, dkk., 2015a). Bukti yang berkembang yaitu kepahlawanan menyediakan manfaat psikologis kepada orang banyak, dalam bentuk sebagai sumber panutan, nilai dan moral. Hal ini menunjukkan butuhnya penelitian lebih lanjut dan klarifikasi tentang konsep "pahlawan" (Kinsella, dkk., 2015a).
Penelitian mengenai pahlawan telah banyak dipublikasikan di Barat. Penelitian yang telah dilakukan tersebut sudah beragam. Mulai dari mengidentifikasi pahlawan dalam sejarah (Jauss, 1974), mendefinisikan pahlawan dalam kehidupan sehari-hari (Porpora, 1996; Keczer, File, Orosz, \& Zimbardo, 2016; Sullivan \& Venter 2010), hingga pemujaan terhadap pahlawan (Klapp, 1949). Penelitian oleh Jauss (1974), mengungkapkan estetika pahlawan dalam sejarah. Pahlawan diidentifikasi pada lima modalitas yaitu asosiatif, kekaguman, simpati, katarsis, dan ironis. Masing-masing memiliki disposisi dan norma perilaku yang positif dan negatif. Sementara Coughlan, dkk. (2017) meneliti pahlawan dikaitan dengan bosan dan pencarian makna hidup.

Selanjutnya Gray dan Wegner (2011) melakukan penelitian mengenai dampak negatif menjadi pahlawan., Franco, dkk., (2011) melakukan penelitian mengenai perbedaan tindakan pahlawan dan altruisme. Berikutnya, Kinsella, dkk., (2015a; 2015b) telah melakukan penelitian mengenai perspektif awam tentang fungsi sosial dan psikologis pahlawan, fitur penting dan fungsi psikologis pahlawan, apa yang orang pikirkan tentang pahlawan dan fungsi sosial dan psikologis mereka, dan penekanan pada pahlawan: analisis prototipe fitur pahlawan.

Di Indonesia, penelitian mengenai nilai-nilai kepahlawanan telah diteliti, seperti yang dilakukan oleh Sulistyani (2008) mengenai penanaman nilai kepahlawanan dalam pembelajaran. Pada penelitian ini ditemukan bahwa cara menanamkan nilai-nilai kepahlawanan dengan melaksanakan kegiatan seharihari. Selanjutnya, penelitian yang tentang nilai kepahlawana melalui film, seperti Kurniawan (2015) melakukan penelitian nilai-nilai kepahlawan dalam kultur Jawa dan Khomsah (2015) mengenai representasi nilai kepahlawanan ditunjukkan melalui simbol-simbol sosial yang ditampilkan dalam tokoh film. Namun demikian penelitian mengenai 
penelitian mengenai pahlawan dalam perspektif psikologi sangat jarang dilakukan. Oleh karena itu, peneliti tertarik untuk meneliti dan mengekplorasi karakteristik pahlawan yang sesuai dengan konteks Indonesia khususnya Pekanbaru Riau.

\section{Metode Penelitian}

Partisipan. Partisipan penelitian sebanyak 300 mahasiswa (194 perempuan, 106 laki-laki) dari Universitas Islam Negeri Sultan Syarif Kasim Riau, Indonesia. Partisipan berusia antara 1825 tahun dengan rerata umur 21 tahun. Subjek dipilih menggunakan teknik accidental sampling, yaitu teknik penentuan sampel berdasarkan kebetulan. Siapa saja yang secara kebetulan bertemu dengan peneliti dapat digunakan sebagai sampel, bila dipandang orang yang kebetulan ditemui cocok sebagai sumber data (Martono, 2012).

Pengukuran. Penelitian ini menggunakan kuesioner yang disusun oleh peneliti berdasarkan hasil studi sebelumnya, (Kim, Yang, \& Hwang, 2006) dan hasil diskusi dengan peneliti di Center for Indigenous Psychology UIN Suska Riau. Data dikumpulkan dengan menggunakan kuesioner dengan pertanyaan terbuka atau open-ended questionnaires. Kuesioner dilengkapi format latar belakang yang berisi data identitas partisipan. Pertanyaan yang digunakan dalam penelitian ini yakni: 1 . Sebutkan salah satu nama yang menurut anda bisa disebut sebagai pahlawan? 2. Apa hubungan anda dengannya (No. 1)? 3. Mengapa anda menilai orang tersebut sebagai pahlawan? Jelaskan!

Analisisi Data. Peneliti menggunakan metode kualitatif dan kuantitatif dengan perspektif psikologi indigenous, yaitu memahami perilaku manausia berdasarkan konteks (Kim dkk., 2006). Oleh karena itu, data yang diperoleh dari kuesioner kemudian dianalisis berdasarkan respon yang ditemukan. Kemudian dikelompokkan lebih umum sehingga ditemukan karakteristik umum dari pahlawan. Pada tahap ini, alat bantu yang digunakan adalah Nvivo 8, yaitu software yang dipakai untuk melakukan analisis data kualitatif. Setelah itu dilakukan validasi kategori yang melibatkan beberapa peneliti di Center for Indigenous UIN Suska Riau. Selanjutnya, data di input dan dianlisis dengan analisis kuantitatif dengan bantuan program SPSS.

\section{Hasil Penelitian}

Hasil penelitian menunjukkan bahwa orangtua, tokoh nasional atau masyarakat dan pendidik merupakan orang yang dianggap sebagai pahlawan oleh mahasiswa. Seperti tampak pada tabel 3, orangtua merupakan pahlawan yang paling dominan, yaitu, lebih dari $50 \%$ responden menyatakan pahlawan mereka adalah orangtua, selanjutnya tokoh nasional/kelompok (19\%) dan pendidik $(16,7 \%)$.

Tabel 1 Pahlawan Menurut Mahasiswa

\begin{tabular}{clcc}
\hline No & Kategori & $\begin{array}{c}\text { Freku- } \\
\text { ensi }\end{array}$ & $\begin{array}{c}\text { Per- } \\
\text { sentase }\end{array}$ \\
\hline 1 & $\begin{array}{l}\text { Orangtua } \\
\text { Tokoh }\end{array}$ & 193 & 64.3 \\
2 & $\begin{array}{l}\text { Nasional / } \\
\text { Masyarakat }\end{array}$ & 57 & 19.0 \\
3 & $\begin{array}{l}\text { Pendidik } \\
\text { Jumlah }\end{array}$ & 50 & 16.7 \\
\hline & $\mathbf{3 0 0}$ & $\mathbf{1 0 0}$ \\
\hline
\end{tabular}

Hasil penelitian menunjukkan ada delapan belas kategori khusus dari karakteristik pahlawan. Kemudian peneliti mengelompokkan karakteristik pahlawan menjadi lebih umum, sehingga ditemukan delapan karakteristik pahlawan. Delapan karakteristik pahlawan tersebut (lihat Tabel 2). Karakteristik pahlawan yang utama yaitu dominan $(24,67 \%)$ terdiri dari berani, dominan, pemimpin dan kuat, seperti respon yang dikemukakan oleh partisipan:

"Karena ibu merupakan salah seorang yang sangat kuat sebagai seorang perempuan. Karena ibu yang telah berjuang untuk 
Tabel 2 Karakteristik Pahlawan di Riau, Indonesia

\begin{tabular}{|c|c|c|c|}
\hline No & Kategori & Frekuensi & Persentase \\
\hline \multirow[t]{5}{*}{1} & Dominan & 74 & 24,67 \\
\hline & Berani & 38 & 12,67 \\
\hline & Mendominasi & 25 & 8.33 \\
\hline & Pemimpin & 8 & 2,67 \\
\hline & Kuat & 3 & 1,0 \\
\hline \multirow[t]{4}{*}{2} & Peduli & 57 & 19,0 \\
\hline & Peduli & 46 & 15,33 \\
\hline & penuh kasih & 7 & 2,33 \\
\hline & Empati & 4 & 1,33 \\
\hline \multirow[t]{3}{*}{3} & Karismatik & 39 & 13,0 \\
\hline & Berdedikasi & 36 & 12,0 \\
\hline & Karismatik & 3 & 1,0 \\
\hline \multirow[t]{3}{*}{4} & Inspiratif & 35 & 11,67 \\
\hline & Menakjubkan & 18 & 6,0 \\
\hline & Inspirasional & 17 & 5,67 \\
\hline \multirow{3}{*}{5} & Tangguh & 29 & 9,66 \\
\hline & Pencapaian & 16 & 5,33 \\
\hline & Tekun & 13 & 4,33 \\
\hline \multirow[t]{4}{*}{6} & Tanpa Pamrih & 27 & 9,0 \\
\hline & Berkorban & 14 & 4,67 \\
\hline & Altruistik & 7 & 2,33 \\
\hline & Tanpa pamrih & 6 & 2,0 \\
\hline \multirow[t]{2}{*}{7} & Mendidik & 26 & 8,67 \\
\hline & Mendidik & 26 & 8,67 \\
\hline \multirow[t]{2}{*}{8} & Terpercaya & 13 & 4,33 \\
\hline & Setia & 13 & 4,33 \\
\hline Jumla & & 300 & 100 \\
\hline
\end{tabular}

melahirkan kita ke dunia dengan mempertaruhkan seluruh jiwa raga dan juga nyawanya untuk berjuang melahirkan seorang anak (S 035), karena ia adalah seorang pejuang rela berkorban (S 205),

"Karena orang tersebut mampu memimpin keluarga dengan baik apapun keadaannya." (R.088)

Karakteristik selanjutnya secara berturut-turut adalah peduli $(19 \%)$, karismatik (13\%), inspiratif $(11,67 \%)$, tangguh $(9,66 \%)$, tanpa pamrih $(9 \%)$, mendidik $(8,67 \%)$ dan terpercaya $(4,33 \%)$. Perbedaan persentase antara satu kategori ke kategori lainnya cukup signifikan. Analisis tambahan untuk melihat perbedaan antara responden lakilaki dan perempuan dalam mengungkapkan karakteristik pahlawan, menemukan hasil bahwa secara umum tidak ada perbedaan antara karakteristik pahlawan yang utama. Pria dan wanita sama-sama melihat bahwa karakter dominan merupakan karakter utama dalam menggambarkan pahlawan, selanjtnya, peduli kharismatik dan inspiratif. Namun terdapat beberapa perbedaan presentase dalam kategori karakteristik pahlawan (lihat tabel 3).

Hasil data cros tabulasi antara siapa pahlawan dengan karakteristik pahlawan menunjukkan bahwa setiap pahlawan memiliki karakter tersendiri dalam 
Tabel 3 Perbedaan Karakteristik Pahlawan Berdasarkan Jenis Kelamin

\begin{tabular}{clclc}
\hline No & \multicolumn{1}{c}{ Laki-laki } & Persentase & \multicolumn{1}{c}{ Perempuan } & Persentase \\
\hline 1 & Dominan & 22,4 & Dominan & 26,4 \\
2 & Peduli & 18,7 & Peduli & 18,7 \\
3 & Karismatik & 14,0 & Karismatik & 12,4 \\
4 & Inspiratif & 14,0 & Inspiratif & 10,4 \\
5 & Tangguh & 10,3 & Tanpa Pamrih & 9,8 \\
6 & Mendidik & 9,3 & Tangguh & 9,3 \\
7 & Tanpa Pamrih & 7,5 & Mendidik & 8,3 \\
8 & Terpercaya & 3,7 & Terpercaya & 4,7 \\
\hline
\end{tabular}

Tabel 4 Karakteristik pahlawan berdasarkan Siapa Pahlawan

\begin{tabular}{|c|c|c|c|c|c|c|}
\hline & \multirow{3}{*}{$\begin{array}{l}\text { Dominan } \\
\text { Dom }\end{array}$} & & \multicolumn{3}{|c|}{ Pahlawan } & \multirow[b]{2}{*}{ Total } \\
\hline & & & $\begin{array}{l}\text { Orang } \\
\text { Tua }\end{array}$ & Pendidik & $\begin{array}{c}\text { Tokoh } \\
\text { Nasional/ } \\
\text { Masyarakat }\end{array}$ & \\
\hline \multirow[t]{16}{*}{ Kategori } & & & 42 & 8 & 25 & 75 \\
\hline & & $\%$ within pahlawan & $21,8 \%$ & $16,0 \%$ & $43,9 \%$ & $25,0 \%$ \\
\hline & \multirow[t]{2}{*}{ Peduli } & \multirow{2}{*}{$\begin{array}{l}\text { Count } \\
\% \text { within pahlawan }\end{array}$} & 49 & 6 & 1 & 56 \\
\hline & & & $25,4 \%$ & $12,0 \%$ & $1,8 \%$ & $18,7 \%$ \\
\hline & \multirow[t]{2}{*}{ Karismatik } & \multirow{2}{*}{$\begin{array}{l}\text { Count } \\
\% \text { within pahlawan }\end{array}$} & 26 & 3 & 10 & 39 \\
\hline & & & $13,5 \%$ & $6,0 \%$ & $17,5 \%$ & $13,0 \%$ \\
\hline & \multirow[t]{2}{*}{ Inspiratif } & \multirow{2}{*}{$\begin{array}{l}\text { Count } \\
\% \text { within pahlawan }\end{array}$} & 23 & 8 & 4 & 35 \\
\hline & & & $11,9 \%$ & $16,0 \%$ & $7,0 \%$ & $11,7 \%$ \\
\hline & \multirow[t]{2}{*}{ Tangguh } & \multirow{2}{*}{$\begin{array}{l}\text { Count } \\
\% \text { within pahlawan }\end{array}$} & 15 & 6 & 8 & 29 \\
\hline & & & $7,8 \%$ & $12,0 \%$ & $14,0 \%$ & $9,7 \%$ \\
\hline & \multirow{2}{*}{$\begin{array}{l}\text { Tanpa } \\
\text { Pamrih }\end{array}$} & \multirow{2}{*}{$\begin{array}{l}\text { Count } \\
\% \text { within pahlawan }\end{array}$} & 17 & 6 & 4 & 27 \\
\hline & & & $8,8 \%$ & $12,0 \%$ & $7,0 \%$ & $9,0 \%$ \\
\hline & \multirow[t]{2}{*}{ Mendidik } & \multirow{2}{*}{$\begin{array}{l}\text { Count } \\
\% \text { within pahlawan }\end{array}$} & 11 & 10 & 5 & 26 \\
\hline & & & $5,7 \%$ & $20,0 \%$ & $8,8 \%$ & $8,7 \%$ \\
\hline & \multirow{2}{*}{ Terpercaya } & Count & 10 & 3 & 0 & 13 \\
\hline & & $\%$ within pahlawan & $5,2 \%$ & $6,0 \%$ & $0,0 \%$ & $4,3 \%$ \\
\hline \multirow[t]{2}{*}{ Total } & & Count & 193 & 50 & 57 & 300 \\
\hline & & $\%$ within pahlawan & $100,0 \%$ & $100,0 \%$ & $100,0 \%$ & $100,0 \%$ \\
\hline
\end{tabular}


menjelaskan karaktersitik pahlawan. Karakteristik pahlawan tertinggi dari orangtua adalah peduli $(25,4 \%)$, dominan $21,8 \%$ ), dan khrismatik (13,5\%), sementara tokoh nasional adalah dominan $(43,9 \%)$, kharismatik $(17,7 \%)$ dan tangguh (14\%) dan pendidik adalah karakter mendidik $(20 \%)$, inspiratif $(16 \%)$ dan dominan (16\%) (lihat Tabel 4).

\section{Diskusi}

Penelitian ini bertujuan untuk mengeksplorasi siapa pahlawan dan karakteristik pahlawan pada mahasiswa. Hasil penelitian menunjukkan bahwa orangtua dianggap sebagai pahlawan dibandingkan tokoh nasional/kelompok dan pendidik. Hasil ini mengindikasikan bahwa yang dinamakan pahlawan adalah orang memiliki pengaruh kuat dan peduli pada diri partisipan. Orangtua merupakan figure sentral bagi individu baik secara langsung dan tindak langsung. Indvidu cenderung mengambarkan siapa pahlawan berdasarkan pengalaman personal (White, 1999). Selain itu, orang tua merupakan sosok yang berada paling dekat dengan individu dibandingkan tokoh nasional/kelompok dan pendidik.

Hasil penelitian ini konsisten dengan penelitian Staats, dkk. (2009) yang menyatakan prototype pahlawan melekat pada anggota keluarga. Senada dengan penelitian Goethals dan Allison, (2012) yang menyatakan bahwa $65 \%$ partisipan menilai pahlawan adalah orangtua dan pendidik. Menurutnya orangtua dan pendidik merupakan pahlawan yang nyata dalam kehidupan sehari-hari, atau yang disebut transparent heroes. Istilah trasnparent heroes merujuk pada pahlawan yang memiliki peran penting dan kontibusi nyata pada individu, namun keberadaanya luput dari perhatian publik. Sementara tokoh nasional atau pimpinan kelompok merupakan pahlawan dengan tipe transforming heroes, yaitu pahlawan yang memiki kemampuan untuk merubah orang lain dan masyarakat melalui aksinya, seperti seperti Bung karno, Muhammmad Hatta, dan lainnya.
Sementara Keczer, dkk. (2016) membagi pahlawan pada dua konteks yaitu pahlawan secara umum, yaitu terjadi pada situasi tertentu dan pahlawan sehari-hari, yaitu pahlawan sering dijumpai sehari-hari. Dia menyebut bahwa orangtua dan pendidik merupakan pahlawan sehari-hari (everyday hero). Pahlawan sehari-hari memiliki batasan dan konsep yang berbeda dengan jenis pahlawan lainnya seperti tokoh nasional, artis, atlet. Pahlawan sehari-hari (orangtua, pendidik) memiliki pengaruh terbatas dan cakupan lebih kecil dibandingkan pahlawan secara luas (Franco, dkk., 2011). Namun demikian pengaruhnya dirasakan nyata dan realistis sehingga partisipan lebih memilih orangtua sebagai pahlawan dalam kehidupannya.

Ada dua element pahlawan, yaitu perilaku yang berkaitan dengan moral, yaitu segala sesuatu yang berkaitan karakter, dan perbuatan positif dan kompetensi, yaitu kemampuan untuk menyelesaikan sesuatu masalah (Goethals \& Allison, 2012).Berdasarkan hasil penelitian ini menunjukkan bahwa terdapat delapan karakteristik pahlawan, yaitu (1) dominan: berani, mendominasi, pemimpin, kuat (2) peduli: peduli, penuh kasih, empati (3) karismatik: berdedikasi, karismatik (4) inspiratif: menakjubkan, inspirasional (5) tangguh: pencapaian, tekun (6) tanpa pamrih: berkorban, altruistik, tanpa pamrih (7) mendidik: mendidik (8) terpercaya: setia. Secara umum banyak kesamaan karakteristik pahlawan berdasarkan penelitian Goethals dan Allison (2012), yaitu (1) peduli (2) karismatik (3) inspiratif: (4) terpercaya (5) tangguh (6) tanpa pamrih (7) pintar (8) kuat/dominan.

Ada satu kategori yang berbeda, yang tidak ditemukan yaitu mendidik di penelitian Goethals dan Allison (2012), dan kategori pintar. Pada penelitian ini. Mendidik yang dimaksud adalah bagaimana seorang pahlawan mampu menyalurkan, menyampaikan, mengajarkan, dan mengayomi individu lain menjadi lebih baik, yang juga berarti berhubungan 
dengan individu lain. Sementara kepintaran, termasuk kecerdasan dan kebijaksanaan adalah sebuah sifat yang dimiliki oleh individu dan tidak berhubungan dengan orang lain.

Pada orangtua, karakteristik pahlawan yang paling tinggi adalah peduli, selanjutnya dominan dan kharismatik. Kepedulian merupakan sifat sentral yang menjelaskan pahlawan pada orangtua. Sementara pada tokoh nasional/ kelompok karakterstik yang paling tinggi adalah dominan khususnya keberanian, sedangkan pada pendidik adalah karakter mendidik. Sementara hasil ini tidak terlalu berbeda dengan penelitian Keczer, dkk. (2016) yang menempatkan karakter penolong sebagai pilihan tertinggi selanjutnya berani, mengutamakan orang lain dan perngorbanan diri pada pahlawan sehari-hari (orangtua dan pendidik). sementara. pahlawan secara umum (tokoh nasional/perjuangan) karakter berani menmpati urutan tertinggi.

Secara umum hasil penelitian ini tidak jauh berbeda dengan penelitian yang dilakukan di Barat. Perbedaan konteks budaya di Indonesia yang cenderung kolektif dibandingkan di Barat yang cenderung indvidualis diasumsikan berperan dalam bagaimana indvidu mengambarkan pahlawan tidak tampak dalam penelitian ini. Konsepsi siapa dan apa karakter pahlawan antara di Indonesia dan di Barat relatif sama. Karakter pahlawan yang muncul yang sama adalah berkaitan dengan nilai, moral dan karakter positif yang melekat pada diri individu konkret (tidak fiksi) dan cenderung pada orang yang memiliki hubungan personal dengan partisipan, seperti orangtua dan guru.

Akhirnya, penelitian ini merupakan langkah awal dalam mengeksplorasi siapa dan apa karaktersitisk pahlawan menurut mahasiswa di Indonesia khsuusnya di Riau. Beberapa Keterbatasan penelitia ini adalah jumlah dan variasi subjek penelitian belum menggambarkan keberagaman subjek sehingga perlu ditambah agar hasil lebih tepat menggambarkan pahlawan. Selain itu, perlu penelitian lanjutan dengan metode yang berbeda untuk menggambarkan faktor dan implikasi nilai kepahlawan pada indvidu dalam konteks sosial.

\section{Kesimpulan}

Pahlawan merupakan suatu konsep penting dalam kehidupan masyarakat dan bernegara. Pahlawan merupakan seseorang indvidu yang mampu memberikan manfaaat baik secara materi maupun psikologis. Dalam diri pahlawan ada nilai-nilai kepahlawan memberikan yang dapat inspirasi dan model bagi pembentukan nilai, dan karakter indvidu dan masyarakat. Konsepsi pahlawaan yang ditemukan dalam penelitian adalah keluarga terutama orangtua. selanjutnya dilanjutkan dengan tokoh nasional/ komunitas dan pendidik. Sementara karakter pahlawan adalah dominan peduli karismatik inspiratif tangguh tanpa pamrih mendidik dan terpercaya. Hasil ini mengindikasikan bahwa siapa pahlawan dan karakteristik pahlawan berlaku umum, artinya temuan ini tidak jauh berbeda pada penelitian dengan budaya berbeda terutama di Barat.

\section{Daftar Pustaka}

Algoe, S., \& Haidt, J. (2009). Witnessing excellence in action: The otherpraising emotions of elevation, admiration, and gratitude. J. Posit. Psychol., 4, 105-127. doi: 10.1080/ 17439760802650519

Allison, S. T., \& Goethals, G. R. (2011). Heroes: What They Do and Why We Need Them. NY: Oxford University Press. NewYork

Bricheno, P., \& Thornton, M. (2007). Role model, hero or champion? Children's views concerning role models, Educational Research, 49(4), 383-396, doi: 10.1080/ 00131880701717230

Cohen, S. (1993). For parents particularly: lessons in moral behavior: A few heroes. Child. 
Educ., 68, 168-170. doi: 10.1080/ 00094056.1993.10520921

Coughlan, G., Igou, E. R., van Tilburg, W. A. P., Elaine L., Kinsella, E. L \& Ritchie, T. D. (2017). On boredom and perceptions of heroes: a meaning-regulation approach to heroism. Journal of Humanistic Psychology, 1-19. doi: 10.1177/0022167817705281

Franco, Z., Blau, K., \& Zimbardo, P. (2011). Heroism: A conceptual analysis and differentiation between heroic action and altruism. Review. General. Psychology, 5, 99-113. doi: $10.1037 / a 0022672$

Goethals, G. R., \& Allison, S. T. (2012). Making deroes: The construction of courage, competence and virtue. Adv. Exp. Soc. Psychol., 46, 183235 . doi: 10.1016/B978-0-12394281-4.00004-0

Gray, K. \& Wegner, D. M. (2011). To escape blame, don't be a hero-be a victim. Journal of Experimental Social Psychology, 47, 516-519. doi: 10.1016/j.jesp.2010.12.012

Harper, D. (2010). Online etymology dictionary. Retrieved from http://www.etym online.com

Jayawickreme, E., \& Stefano, P. O. (2012). How can we study heroism? Integrating persons, situations and communities. International Society of Political psychology: Political Psychology, 33(1), 165-178. doi: 10.1111/j.1467-9221.2011.00861.x

Jauss, H. R. (1974). Levels of identification of hero and audience. New Literary History, 5(2), 283-317. doi: $10.2307 / 468397$

Keczer, Z., File, B., Orosz, G., \& Zimbardo P. G. (2016) Social Representations of hero and everyday hero: A network study from representative samples. PLoS ONE 11(8): e0159354. doi: $10.1371 /$ journal.pone.0159354

Khomsah, S. (2015). Representasi nilai kepahlawanan tokoh Jaleswari dalam film batas "Antara keinginan dan kenyataan" (Analisis semiotic terhadap tokoh Jaleswari). (Skripsi, tidak dipublikasikan). Universitas Negeri Sunan Kalijaga Yogyakarta

Klapp, O. E. (1969). Collective search for identity. NY: Holt, Rinehart, and Winston. NewYork.

Kim, U., Yang, KS., \& Hwang, KK. (2006). Indigenous and cultural psychology: Understanding people in context. Springer. Taiwan.

Kinsella, E. L., Ritchie, T. D., \& Igou, E. R. (2010). Essential features and psychological functions of heroes. Poster session presented at the Northern Ireland. British Psychological Society Annual Conference, Enniskillen

Kinsella, E. L., Ritchie, T. D., \& Igou, E. R. (2015a). Zeroing in on heroes: A prototype analysis of hero features. J. Pers. Soc. Psychol. 108, 114127. doi: $10.1037 / a 0038463$

Kinsella, E. L, Ritchie, T. D., \& Igou, E. R. (2015b). Lay perspective on the social and psychological functions of heroes. Frontiers in psychology, 6, 1-12. doi: 10.3389/fpsyg.2015.00130

Kurniawan, Y. A. (2015). Representasi kepahlawanan orang Jawa dalam Film Java Heat. Diakses dari http://download.portalgaruda.org/arti cle.php?...Representasi\%20Kepahla wanan\%200rang\%.

Kamus Besar Bahasa Indonesia (KBBI). (2016). Pahlawan. Diakses dari https://kbbi.web.id/

Martono, N. (2012). Metode penelitian kuantitatif: analisis isi dan analisis data sekunder. (Red. Ed.). PT RajaGrafindo Persada. Jakarta

Porpora, D. V. (1996). Personal heroes, religion, and transcendental metanarratives. Sociological Forum, 11(2), 209-229

Sulistyani. (2008). Penanaman Nilai Kepahlawanan dalam Pembelajaran IPS Sekolah Dasar (SD) di Daerah Binaan (DABIN) IV Cabang Dinas Pendidikan Kecamatan Semarang Timur. (Tesis, tidak dipublikasikan). Universitas Negeri Semarang. 
Sullivan, M. P., \& Venter A. (2010). Defining heroes through deductive and inductive investigations. The Journal of Social Psychology, 150(5): 471484.doi: 10.1080/00224540903366602

Sullivan, M. P., \& Venter, A. (2005). The hero within: Inclusion of heroes into the self. Self Identity 4, 101-111. doi: 10.1080/13576500444000191

Staats, S., Wallace, H., Anderson, T., Gresley J, Hupp JM, \& Weiss E.
(2009). The hero concept: self, family, and friends who are brave, honest, and hopeful. Psychological Report, 104(3), 820-832, doi: 10.2466/PR0.104.3.820-832

White, S. H. (1999). What is a Hero? An exploratory study of students' conceptions of heroes, Journal of Moral Education, 28(1), 81-95, doi: $10.1080 / 030572499103322$ 